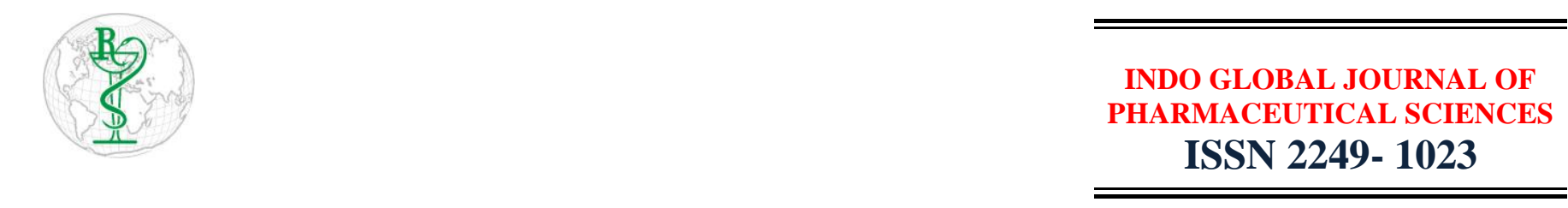

\title{
Ganga Water Kills the Entero-pathogenic Bacteria of Human In Vitro and In Vivo
}

\author{
Shivani Tyagi *, R.C. Dubey * \\ Department of Botany and Microbiology, Gurukula Kangri Vishwavidyalaya, Haridwar-249404, India
}

Address for Correspondence: Shivani Tyagi, dr.shivanityagi@gmail.com ; R.C. Dubey, profrcdubey@gmail.com

Received:
24.07.2019
Accepted:
27.12.2019
Published:
03.11 .2020
Keywords
Albino mice;
Antibacterial;
Entero-
pathogens;
Ganga river
water; Heat-
labile; In vitro; In
vivo.

Received:

24.07.2019

Accepted:

27.12.2019

Published:

03.11.2020

Keywords

Albino mice

Antibacterial

Ganga river

water; Heat-

vivo.
ABSTRACT: River Ganga is considered as one of the most pious rivers of the world since the ancient time due to its self-cleansing property. Therefore, its water has traditionally been used for religious purposes. A total of $4 \times 103 \mathrm{cfu} / \mathrm{ml}$ of residential microflora from Ganga water of Haridwar was screened on selective media. The three standard pathogenic bacteria viz., Escherichia coli, Salmonella typhi and Klebsiella pneumoniae were inoculated in different types of water such as fresh water, three-years stored water, boiled water and tap water. None of the isolated bacteria were found pathogenic among the residential population. The freshly collected Ganga water was more potential for gradual killing of E. coli and K. pneumoniae as compared to S. typhi in vitro and in vivo. Moreover, the fresh and stored filtered water possessed the growth inhibitory property against the pathogens. But this property got lost after boiling the Ganga water. Inhibitory effect of Ganga water on the antibiotic-resistant standard pathogens was also tested in vivo on albino mice. A decrease in growth of antibiotic resistant marker strains of pathogen in the fecal matter of test mice showed the bactericidal property of Ganga water. Some TLC-separated compounds of Ganga water imparted antibacterial property by killing the entero-pathogenic bacteria of human in vivo. Moreover, loss in antibacterial properties upon boiling of water indicated the presence of heat-labile antibacterial agents in Ganga water. This is the first report on bactericidal properties of Ganga water in vivo using albino mice. () 2020 iGlobal Research and Publishing Foundation. All rights reserved.

Cite this article as: Tyagi, S.; Dubey, R.C. Ganga water kills the entero-pathogenic bacteria of Human in vitro and in vivo. Indo Global J. Pharm. Sci., 2020; 10(1): 43-49. DOI: http://doi.org/10.35652/IGJPS.2020.10106.

\section{INTRODUCTION}

Ganga River originates from Gaumukh $\left(30^{\circ} 36^{\prime} \mathrm{N} ; 7^{\circ} 04^{\prime} \mathrm{E}\right)$ in the snout of Gangotri Glacier as Bhagirathi River at the Higher Himalaya and falls into the Bay of Bengal after travelling thousands kilometer. The Ganga river is regarded as one of the most holy and sacred rivers of the world since the time immemorial. The water of the river Ganga is frequently used for drinking, cooking, and bathing purposes because of ancient religious belief. Surprisingly, Ganga water does not putrefy even after long period of storage [1, 2]. Further, Ganga water has also been used for remedial purposes. Most religious beliefs involve some ceremonial use of 'holy' water. The river Ganga is mentioned in the earliest Hindu scripture, Rigveda $(7500$ BC) [3] under the continuous Saraswati-Indus civilization. In $500 \mathrm{BC}$, Hippocrates wrote about the wound healing ability of Ganga water. Ganga river bath is known to cure the leprosy [4]. Outbreaks of acute diarrhoeal disease have been identified as causes of fatal disease as mentioned in the Sanskrit literature and during Hippocratic times [5]. Cure of diarroea and cholera by using Ganga and Yamuna water has been reported earlier [6]. Millions of devotees come every year for holy dips in this river in Rishikesh and Haridwar during auspicious festivals such as Kumbha and Kanwar Melas and bring holy water to store for ritual purposes. Dramatic increase in number of fecal coliforms including Escherichia coli has also been reported in Ganga water [7].

Human enteric bacterial enter in river water through the discharge of sewer and anthropogenic activities. E. coli causes infection in humans and animals. E. coli $\mathrm{O} 157: \mathrm{H} 7$ is a major enteropathogen responsible for causing outbreaks of 


\section{Indo Global Journal of Pharmaceutical Sciences, 2020; 10(1): 43-49}

haemorrhagic colitis and haemolytic uremic syndrome [8]. It caused infection at a very low cell numbers [9]. Salmonella typhi after drinking of water gets adhered onto the epithelium of small intestine and spreads to lymphoid tissues, blood, liver and gall bladder causing typhoid fever. Klebsiella sp. causes many diseases in human including pneumonia, urinary tract infection, wound and surgical infection, cholecystitis, upper respiratory tract infection, osteomyelitis, bacteremia and septicemia. There is a widespread development of antibioticresistance in pathogenic bacteria; hence, the search of new alternative strategies to control the microbial infections is urgently required $[10,11]$. There has been increasing interest of researchers to develop an alternative treatment including antimicrobial peptides, proteins, and nano-particles [12]. The Government of India has proposed to investigate the medicinal properties of Ganga water as claimed in the ancient literature [13]. No work has been done on medicinal properties of Ganga water so far using animal models. The present study was designed to investigate the antibacterial properties of River Ganga water in vitro as well as in vivo employing standard human entero-pathogens and albino mice.

\section{MATERIALS AND METHODS}

\section{Study Area}

Haridwar city is located on the bank of the Ganga river in Uttarakhand (India). It expands from $29^{\circ} 95^{\prime}$ latitude in the North to $78^{\circ} 17^{\prime}$ longitude in the East and has an average of 289 meters elevation. Har ki Pauri (Haridwar) lies between 29 $9^{\circ} 6^{\prime} 44.4840^{\prime \prime} \mathrm{N}$ and 78 ${ }^{\circ} 9^{\prime} 51.2856^{\prime \prime} \mathrm{E}$ (Map 1).

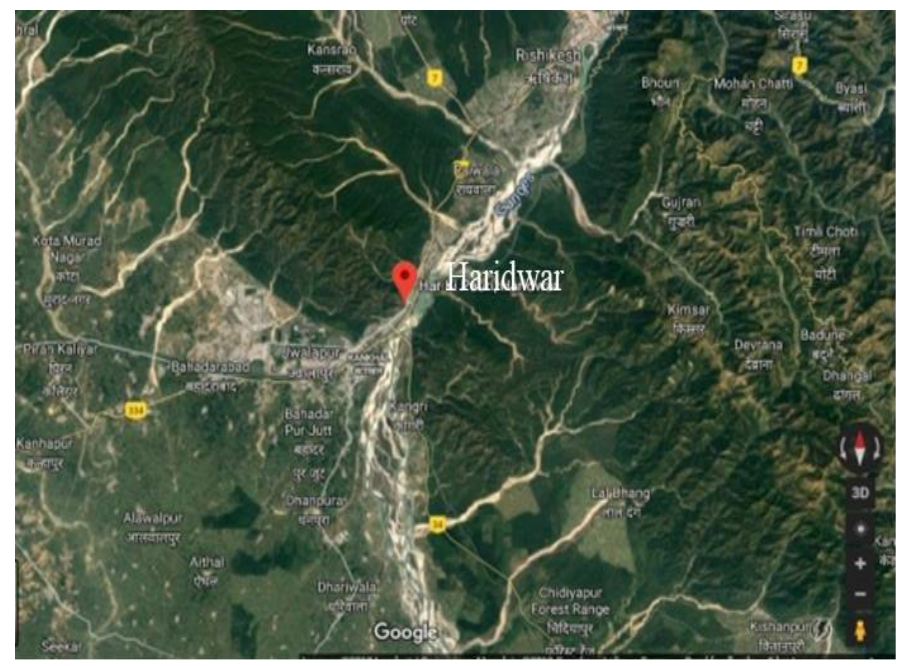

Map 1: A map of sampling site, Haridwar

\section{Sample Collection of Ganga Water}

The water samples were collected from Har ki Pauri in September 2015 and stored for 3 years in screw capped glass bottles in a cool dark space in the research laboratory, Department of Botany and Microbiology, Gurukula Kangri
Vishwavidyalaya and fresh Ganga water was collected in November 2018. The fresh and stored Ganga water was filtered slowly through vacuum filtration assembly with nylon membrane filter $(0.45 \mu$ pore size, $47 \mathrm{~mm}$ diam $)$. In another set of the experiment, the Ganga water was boiled at $100^{\circ} \mathrm{C}$ for 20 min to kill the microorganisms. Tap water acted as control for the comparative analysis with Ganga water.

\section{Heterogeneous Bacterial Count of Ganga water}

Serial dilution of Ganga water samples was prepared, spread on the plates of nutrient agar medium (NAM) and incubated at $37^{\circ} \mathrm{C}$ for $48 \mathrm{~h}$. The bacterial colonies growing on medium were counted using a colony counter. The heterogeneous bacterial counts were elucidated for the detection of Escherichia coli, Salmonella typhi and Klebsiella pneumoniae in Ganga water. The specific growth media used for isolation of bacteria were MacConkey sorbitol medium for E. coli, Wilson-Blair medium for S. typhi and Klebsiella selective agar base medium for $K$. pneumoniae. The individual colony of each bacterium was picked up and streaked on respective selective medium to confirm the presence of any pathogenic strains of the above test bacteria.

\section{Test Organisms}

Three standard cultures of human enterio-pathogenic bacteria viz., Escherichia coli ATCC 27853, Salmonella typhi MTCC 733 and Klebsiella pneumoniae MTCC 432 were procured from the Institute of Microbial Technology (IMTECH), Chandigarh. Bacterial strains were maintained on nutrient agar slants for further use. Log phase culture of each bacterium was prepared by inoculating in nutrient broth and incubated at $37^{\circ} \mathrm{C}$ for $24 \mathrm{~h}$.

\section{Antibacterial property of Ganga water in vitro}

Each selected bacterial strain was grown on nutrient broth. The overnight grown culture of each bacterium was centrifuged $\left(3000 \mathrm{rpm}, 10 \mathrm{~min}, 4^{\circ} \mathrm{C}\right)$ and the pellets were separately washed thrice in $0.85 \%$ phosphate buffer saline (PBS, pH 7.4). The pellets were dissolved in $200 \mu \mathrm{L}$ PBS to get the final concentration of $6 \times 10^{8} \mathrm{cfu} / \mathrm{ml}$ of each bacterium. The bacterial suspension $(200 \mu \mathrm{L})$ was inoculated in $10 \mathrm{ml}$ of different types of water viz., fresh raw water, fresh filtered water, stored raw water, stored filtered water, boiled Ganga water and tap water in polypropylene tubes. All inoculated tubes in triplicates were incubated at $37^{\circ} \mathrm{C}$ in static condition and the growth of all the bacterial species was measured at $595 \mathrm{~nm}$ by using a microtiter plate in Microplate reader (Model 1575) and counting the $\mathrm{cfu} / \mathrm{ml}$ by pouring $1.0 \mathrm{ml}$ of test sample on nutrient agar medium respectively from 0 to 15 days of incubation [14]. Optical density of growth of each bacterium was set 0.05 on the first day by using standard 
McFarland standard.

\section{Thin Layer Chromatography}

Thin layer chromatography plate $(20 \times 20 \mathrm{~cm}$, thickness 0.1 $\mathrm{mm}$ ) was prepared using silica gel "G" (Merck, India). After drying, the plate was activated by heating at $100-110^{\circ} \mathrm{C}$ for 30 min. fresh and boiled Ganga water samples were separately spotted onto the plates using a graduated micropipette (30.0 $\mu 1)$. Solvent system was prepared using n-Butanol: acetic acid: water in 3:1:1 ratio. TLC was run in a closed glass chamber for 2-3 $\mathrm{h}$ to raise the solvent. The plate was dried and ninhydrin reagent was sprayed over the gel to develop the colored spot. The Rf values of each colored spot were measured and scraped off by using a sterile spatula. The scraped compounds were further dissolved in 10\% DMSO (Dimethyl sulfoxide) solvent and centrifuged at $4000 \mathrm{rpm}$ for $10 \mathrm{~min}$. The supernatant of each compound was used for further analysis.

Antibacterial activity of TLC-separated compounds from Ganga water against human entero-pathogens

Thin layer chromatography (TLC)-separated purified compounds were used to analyze the antibacterial activity against E. coli ATCC 27853, S. typhi MTCC 733 and $K$. pneumoniae MTCC 432 by standard well diffusion method on Muller Hinton agar (MHA) plates. Log phase culture of each bacterium was prepared by inoculating in nutrient broth and incubated at $37^{\circ} \mathrm{C}$ for $24 \mathrm{~h}$. Thereafter, $1.0 \mathrm{ml}$ of each strain was spread on solidified MHA plates. Wells were cut in each plate and $50 \mu 1$ of each separated compound was added into the wells. Compound-free solvent was used as control. All plates were incubated at $37^{\circ} \mathrm{C}$ for $24 \mathrm{~h}$ to observe the antibacterial activity of TLC-separated compounds by measuring the zone of inhibition.

\section{Antibiotic Marker Tagging}

Octa-antibiotic discs were used to select the antibioticresistant strain of E. coli, S. typhi and K. pneumoniae on the basis of antibiotic sensitivity test. Then resistant marker strains were developed by subjecting the individual bacterial culture successively from low concentration to high concentrations of streptomycin and tetracycline viz., 10, 20,30, and so on upto $100 \mu \mathrm{g} \mathrm{ml}^{-1}$ for selection of E.coli. Similarly, ciprofloxacin and novobiocin were used for development of resistance in $S$. typhi, and erythromycin and fusidic acid in K. pneumoniae. Antibiotic-resistant marker strains of all three pathogenic bacteria were designated as $E$. coli $^{\mathrm{Str}, \mathrm{Tet}}, S$. typhi $^{\mathrm{Cip}, \mathrm{Nov}}$ and $K$.

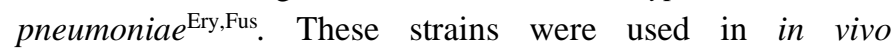
experiment.

\section{Antibacterial property of Ganga water in vivo}

The in vivo antibacterial property of fresh Ganga water was studied on albino mice in the Animal House (Reg. No.: 1324/a/10/CPCSEA) of the Department of Pharmaceutical Sciences, Gurukula Kangri Vishwavidyalaya (Haridwar). Albino mice (4-5 weeks old with an average body weight of 20-25 g) were kept under the standard conditions and a standard pellet diet (Hindustan Lever Products Limited, Kolkata, India) was given to them. Before the start of experiment, water, feed and animals were observed for any contamination and presence of pathogens. The mice were divided into six groups and each group contained six mice as below:

Group 1- (Vehicle control): Received E. coli ${ }^{\mathrm{Str} \text { Tet }}$

Group 2- (Vehicle control): Received S. typhi ${ }^{\mathrm{Cip}, \mathrm{Nov}}$

Group 3 - (Vehicle control): Received K. pneumoniae Ery,Fus $^{\text {. }}$

Group 4 - (Test substance): Received E. coli $^{\mathrm{Str} \text { Tet }}$ and Ganga Water

Group 5- (Test substance): Received S. typhicip,Nov and Ganga Water

Group 6- (Test substance): Received K. pneumoniae ${ }^{\text {Ery,Fus }}$ and Ganga water

All the mice were administered orally $\left(6 \times 10^{8} \mathrm{cfu} / \mathrm{ml}\right)$ with antibiotic-resistant entero-pathogenic bacteria, i.e. E. coli $^{\mathrm{Str}, \mathrm{Tet}}$,

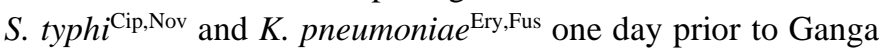
water treatment. Then fresh Ganga water was administered to the test mice for drinking, while sterile water ad libitum to the vehicle control groups. Fresh fecal samples of each animal group were collected from 0 to 20 days of the experimental trial by anal stimulus, weighed, diluted 100 -fold, and homogenized. Serial tenfold dilutions were made and $0 \cdot 1 \mathrm{ml}$ aliquots were poured on the surface of respective selective growth medium supplemented with specific antibiotics to ascertain the presence of $E$. coli ${ }^{\mathrm{Str}, \mathrm{Tet}}, S$. typhi ${ }^{\mathrm{Cip}, \mathrm{Nov}}$ and $K$. pneumoniae $^{\text {Ery,Fus. }}$

\section{RESULTS AND DISCUSSION}

\section{Heterogeneous Bacterial Count of Ganga water}

The heterogeneous bacterial counts were elucidated for the detection of pathogenic E.coli, S. typhi and K. pneumoniae in Ganga water. A total of $4 \times 10^{3} \mathrm{cfu} / \mathrm{ml}$ of heterogeneous population bacteria was measured. The heterogeneous population of bacteria was found in Ganga water but none of them were pathogenic in nature. In our study, the heterogeneous bacterial count of Ganga water was found within limit as prescribed in the Indian Standards Institute [15]. 
Indo Global Journal of Pharmaceutical Sciences, 2020; 10(1): 43-49
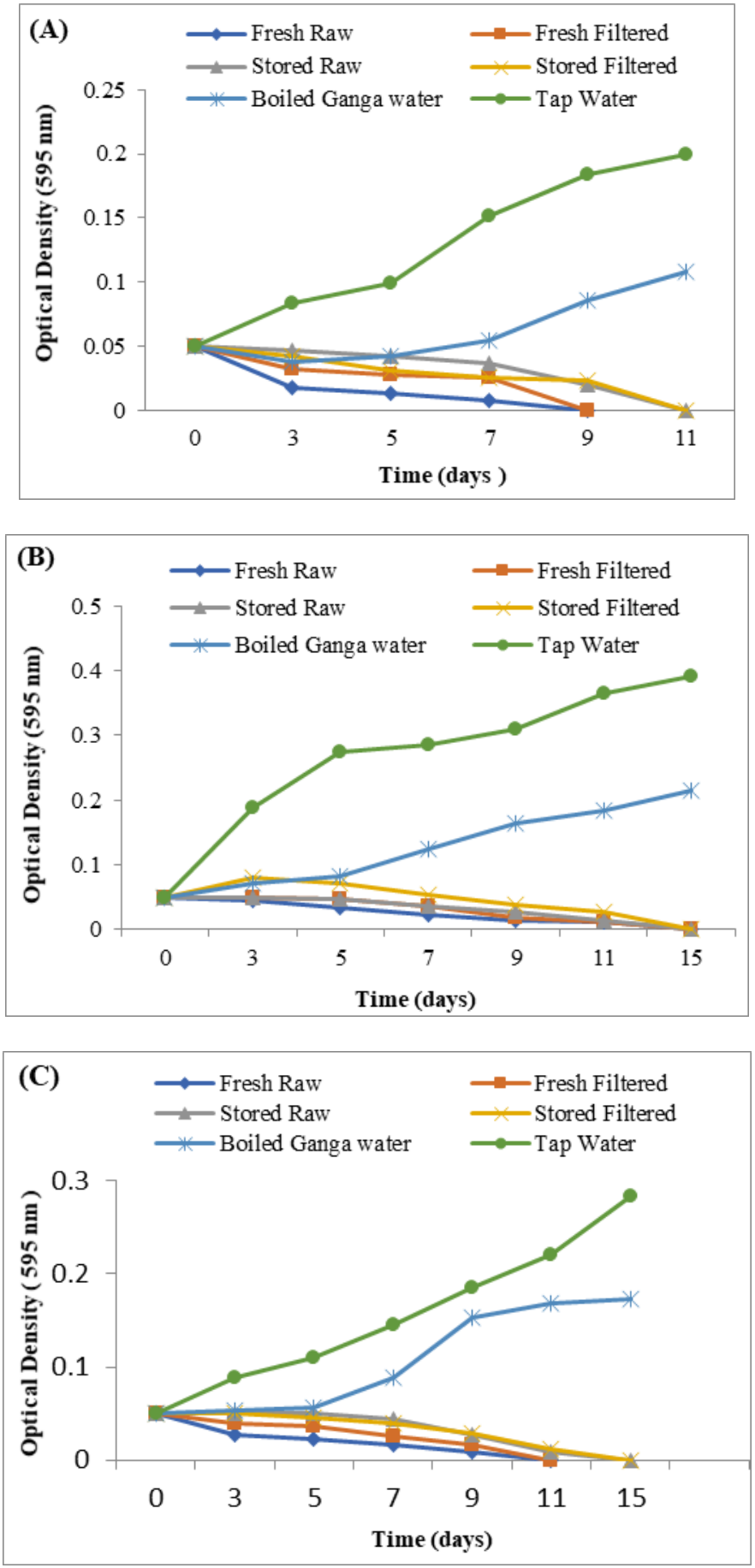

Figure 1. Antibacterial property of Ganga water on growth of bacteria in vitro. A- E. coli; B- S. typhi; C- K. pneumoniae.

This increase in microbial load in Ganga water was due to diverse bacterial species coming through different cities located on the bank of Ganga as well as superfluous water from different rivers and springs. Gradual increase in microbial load from upper to lower Gangetic region would have been due to drainage of sewer and discharge of flowers, detergents, milk, ashes of departed persons, etc. in Haridwar.
Anthropogenic activities extensively have impact on the bacterial population in Ganga water. Mass bathing by millions of devotees in river Ganga contaminates the water during special occasions like Kanwar mela, Kumbh mela, Purnima, etc. via increasing the load of fecal coliforms and changing the water quality $[16,6]$.
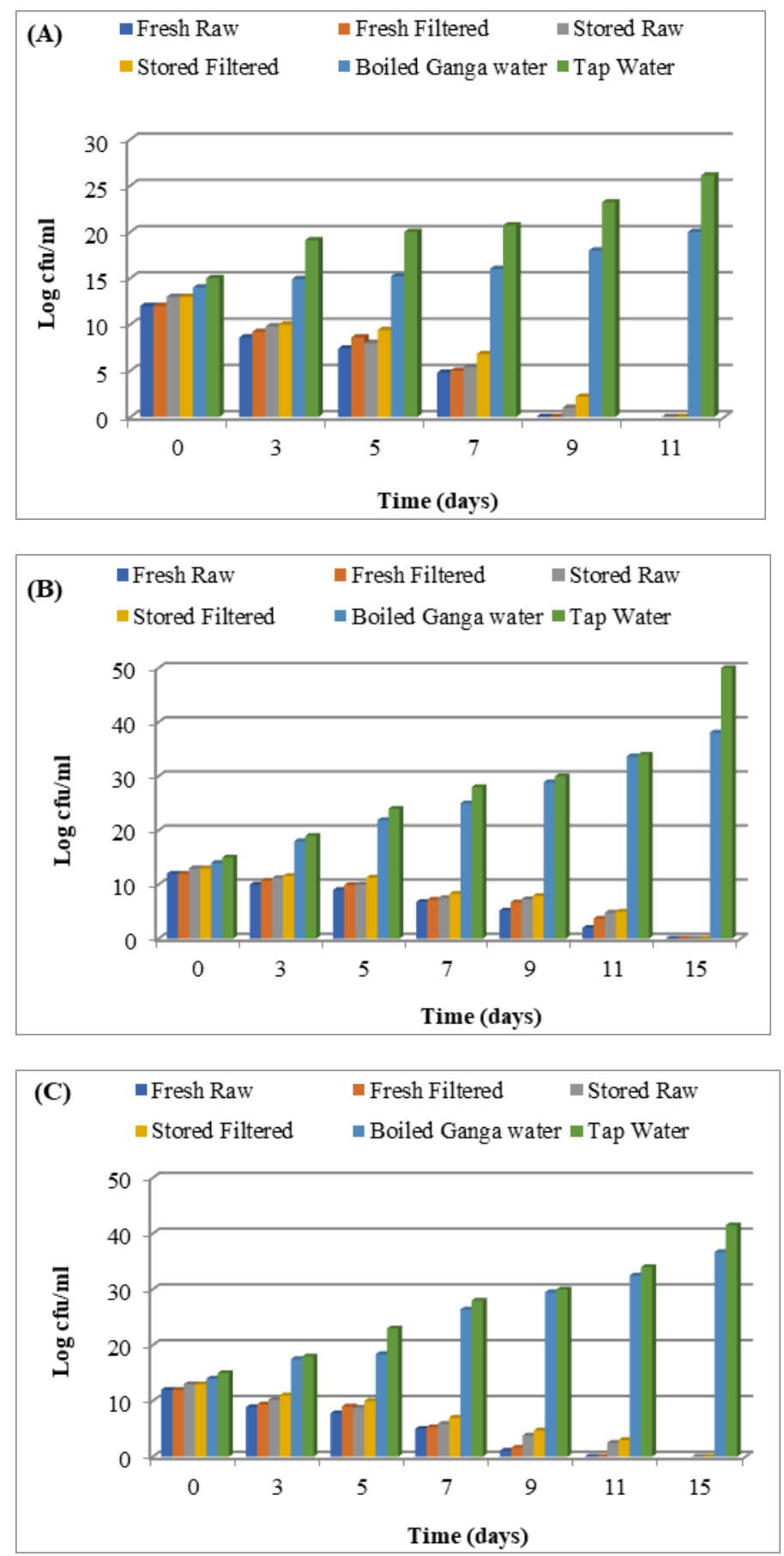

Figure 2. Effect of Ganga water on growth of bacteria in vitro. A- E. coli; B-S. typhi; C- K. pneumoniae. 
Indo Global Journal of Pharmaceutical Sciences, 2020; 10(1): 43-49

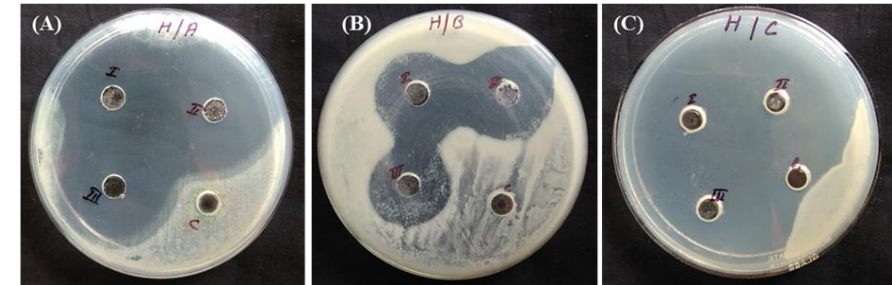

Figure 3. Effect of TLC-separated compounds of Ganga water on growth of entero-pathogens. A- E. coli; B- $S$. typhi; C- K. pneumoniae.

Table 1: Antibacterial activity of TLC-separated compounds of different $R_{f}$ values from Ganga water.

\begin{tabular}{|c|c|c|c|}
\hline \multirow{2}{*}{$\begin{array}{l}\text { Different } \\
\text { Rf values }\end{array}$} & \multicolumn{3}{|c|}{ Zone of Inhibition (mm)* } \\
\cline { 2 - 4 } & E. coli & S. typhi & $\begin{array}{c}\text { K. } \\
\text { pneumoniae }\end{array}$ \\
\hline 0.21 & $22.0 \pm 1.73$ & $12.7 \pm 0.58$ & $23.3 \pm 1.15$ \\
\hline 0.40 & $23.0 \pm 1.00$ & $16.7 \pm 0.58$ & $24.0 \pm 0.00$ \\
\hline 0.55 & $22.3 \pm 1.15$ & $11.3 \pm 0.58$ & $24.7 \pm 0.58$ \\
\hline
\end{tabular}

*Values are mean of triplicates \pm Standard deviation

\section{Antibacterial property of Ganga water in vitro}

Ganga water having a residential bacterial population of $4 \times 10^{3}$ $\mathrm{cfu} / \mathrm{ml}$ was inoculated in a polypropylene tube $(20 \mathrm{ml})$ containing $6 \times 10^{8} \mathrm{cfu} / \mathrm{ml}$ of $E$. coli, S. typhi and $K$. pneumoniae, separately. The in vitro antibacterial property of Ganga water was studied in different type of water viz., fresh raw, fresh filtered, stored raw, stored filtered water, boiled Ganga water and tap water. The growth of all three pathogenic bacteria gradually declined after 15 days of inoculation except tap water and boiled Ganga water. The growth of E. coli was completely inhibited on $9^{\text {th }}$ day (Figures 1A; Figure 2A) in fresh raw and fresh filtered water while that of $S$. typhi was a litter higher and zero on $15^{\text {th }}$ day of inoculation (Figures 1B; Figure 2B). K. pneumoniae displayed a little growth in fresh raw and fresh filtered water on $9^{\text {th }}$ day which completely declined to zero on $11^{\text {th }}$ day (Figures 1C; Figure 2C). The viable count of $E$. coli was substantially inhibited in stored water on $9^{\text {th }}$ day of inoculation and completely on $11^{\text {th }}$ day. Similarly, the growth of $S$. typhi and $K$. pneumoniae was inhibited on $9^{\text {th }}$ day of inoculation and zero on $15^{\text {th }}$ day. The pathogenic bacteria survived more in stored water than the fresh water. Moreover, the numbers of all the bacterial species increased sharply and survived for longer period in boiled and tap water. S. typhi showed higher survival in Ganga water as compared to the rest of two bacteria. E.coli and K. pnumoniae died within 11 days, while $S$. typhi died after 15 days. The antibacterial property of Ganga water gradually declined upon storage for long period. But in boiled Ganga water, the bacteria survived and the population gradually increased with incubation time. In filtered water, the bacterial growth declined as compared to the boiled Ganga water. E. coli, S. typhi and K. pneumoniae survived for 9, 15 and 9 days in fresh raw and fresh filtered water, respectively. But in boiled and tap water, the viable count of all three bacteria increased sharply with time (Figure 1A-C; Figure 2A-C).
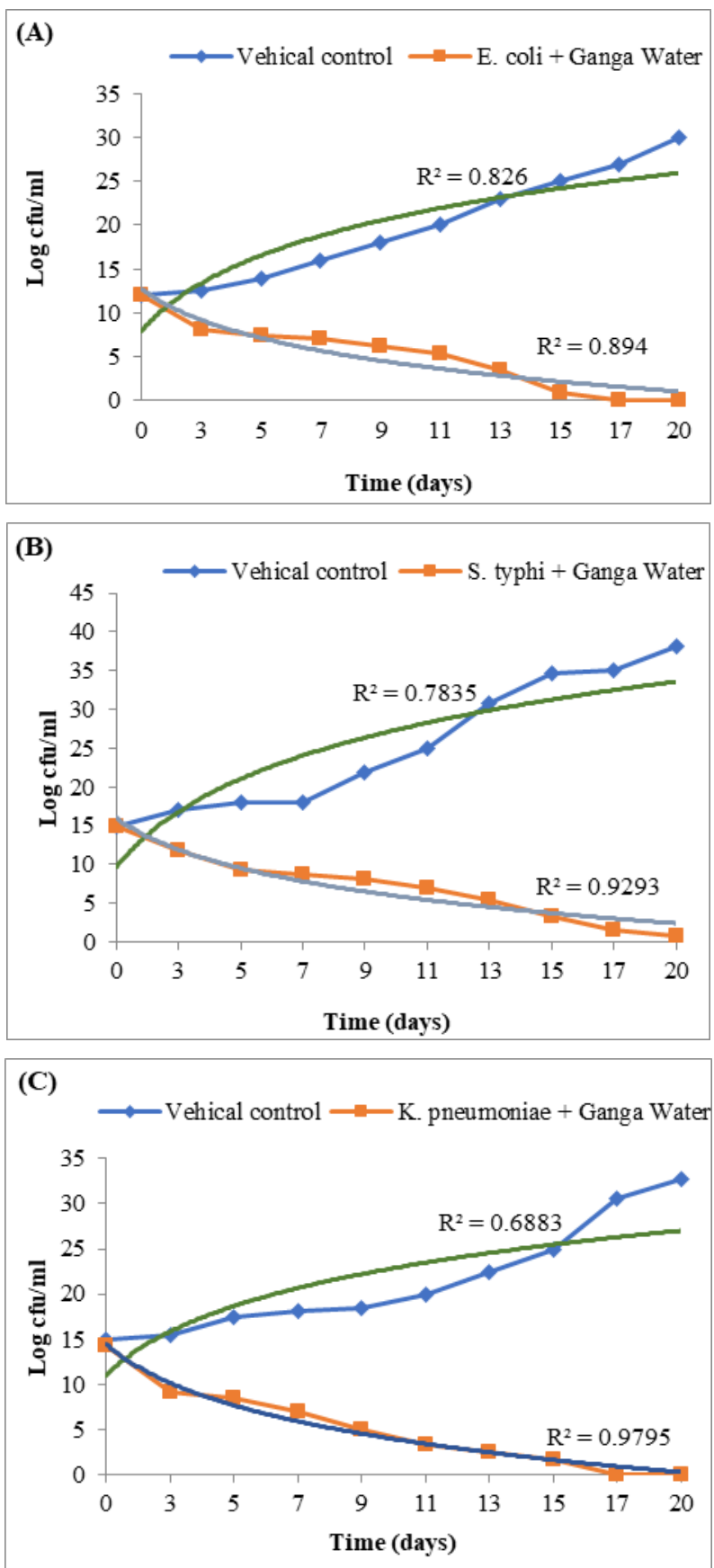

Figure 4. Antibacterial property of Ganga water on growth of bacteria in vivo. A- E. coli ${ }^{\mathrm{Str}, \mathrm{Tet}}$; B-S. typhi ${ }^{\mathrm{Cip}, \mathrm{Nov}}$; C- K. pneumoniae ${ }^{\text {Ery,Fus }}$.

The antibacterial activity of Ganga and Yamuna water against Vibrio cholerae has been reported [6]. Antibacterial property of Ganga water against E. coli, S. typhi and $K$. pneumoniae may be attributed due to the presence of chemical agents present in Ganga water which become inactivated after 
Indo Global Journal of Pharmaceutical Sciences, 2020; 10(1): 43-49

boiling. Hence, the presence of heat-labile antibacterial chemicals becomes ascertained in Ganga water. Earlier bactericidal properties of Ganga water only on pathogenic $E$. coli 0157: H7 in vitro have also been reported [17].

Moreover, the heterogeneous bacterial population of river with pollution as well as inoculation with the pathogenic load of microbes did not affect the natural antibacterial property of this Holy River. The pathogens gradually grew in the tap water possibly due to the absence of inhibitory agents. Survival of the pathogenic bacteria depends on the nutrients available in river water, temperature, flow rate of the river and other physico-chemical factors [18]. The flow rate of river Ganga water also influenced the bacterial population. The number of bacteria decreased in river water with increase in flow rate at Har ki Pauri, Haridwar (author's unpublished data). The source of inhibitory chemicals in Ganga water may be attributed to the melting of glacier as well as heavy rains occurring in the central Himalaya causing soil erosion and dislodging off the chemicals in Ganga water.

\section{Antibacterial activity of TLC-separated compounds from fresh Ganga water against human entero-pathogens}

A total of three compounds were separated from fresh Ganga water of Haridwar. The compounds have the Rf value 0.21, $0.40,0.55$ but none of the compounds were found in boiled Ganga water. The purified TLC-separated compounds were used to analyze the antibacterial activity against E. coli, $S$. typhi and $K$. pneumoniae by standard well diffusion method on Muller Hinton Agar (MHA) plates. The compounds separated from the Rf value 0.40 showed the highest growth inhibitory activity against all three entero-pathogens. All three compounds resulted in the highest zone of inhibition against E. coli and K. pneumoniae, whereas less zone of inhibition against $S$. typhi was recorded (Table 1, Figure 3A-C). The loss of antibacterial property upon boiling of Ganga water would have been due to denature of chemicals at high temperature.

\section{Antibacterial property of Ganga water in vivo}

The fecal samples of all the groups of albino mice were collected and presence of antibiotic-resistant bacteria was measured by counting cfu on specific growth media separately amended with specific antibiotics. The total viable counts of E. coli $^{\mathrm{Str}, \mathrm{Tet}}$ was subsequently declined to half $(12 \mathrm{log} \mathrm{cfu} / \mathrm{ml}$ to $6.2 \log \mathrm{cfu} / \mathrm{ml})$ on $9^{\text {th }}$ day and to zero on $17^{\text {th }}$ days of feeding (Figure 4A). A gradual decrease in $S$. typhi ${ }^{\mathrm{Cip}, \mathrm{Nov}}$ and $K$.

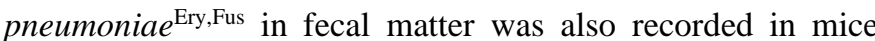
group treated with Ganga water. Initially the viable count of $S$. typhi $i^{\mathrm{Cip}, \mathrm{Nov}}$ was decreased to $6.9 \mathrm{log} \mathrm{cfu} / \mathrm{ml}$ on $11^{\text {th }}$ day and 0.7 $\log \mathrm{cfu} / \mathrm{ml}$ on $20^{\text {th }}$ day (Figure 4B). Similarly, initial viable count of $K$. pneumoniae ${ }^{\text {Ery,Fus }}$ gradually decreased to half (7 $\log \mathrm{cfu} / \mathrm{ml}$ ) on $9^{\text {th }}$ day and zero on $17^{\text {th }}$ day of feeding (Figure 4C). Among all three pathogens, the speed of growth inhibition of $S$. typhicip,Nov was slower than the rest of two other bacteria. The number of all three pathogenic bacteria decreased in the fecal matter of mice treated with Ganga water. Fecal material has been used to detect the survived enteric pathogens. A similar study has also been conducted on exoproducts of the Escherichia coli strain $\mathrm{H} 22$ inhibiting some enteric pathogens in vitro and in vivo [19]. Ours is the first report on bactericidal properties of Ganga water killing enteropathogenic bacteria in vivo in mice. Earlier we also reported the presence of three bacteriophages of these three pathogens in Ganga water [20]. Therefore, these two factors may be responsible for non-putrifying properties of Ganga water.

\section{CONCLUSION}

It may be concluded that the Ganga water possesses some specific antibacterial heat-labile compounds that play a major role in killing the bacteria and maintaining the purity of Ganga water. The presence of these antibacterial compounds imparts the purificatory activity to Ganga water that makes it capable of not being spoiled even after prolonged storage. Ganga river also possesses the ability to kill entero-pathogenic bacteria of human in vitro and in vivo. But loss of antibacterial properties after boiling of water indicated the presence of heat-labile antibacterial agents in Ganga water. This is the first report on bactericidal properties of Ganga water in vivo using albino mice.

\section{ACKNOWLEDGEMENT}

The authors wish to thank the Head, Department of Botany \& Microbiology for providing laboratory facility and the Head, Department of Pharmaceutical Sciences of Gurukula Kangri Vishwavidyalaya for providing facilities of Animal House for in vivo experiments.

\section{CONFLICTS OF INTEREST}

The authors declare that they have no conflict of interest.

\section{DATA AVAILABILITY}

Not declared.

\section{FUNDING AGENCY}

No external funding declared.

\section{REFERENCES}

[1] Darian, S.G. The Ganges in myth and history. University Press of Hawaii, Honolulu, 1978.

[2] B Sharma, Y. The Ganga, India. In: Water pollution control-a guide to the use of water quality management principles. Eds: Helmer R and Ivanildo H WHO/UNEP, Geneva, 1997.

[3] Rigveda 10.75.5.

[4] Kloss, J. Back to Eden. Back to Eden books, Loma Linda, 1939. 
Indo Global Journal of Pharmaceutical Sciences, 2020; 10(1): 43-49

[5] McMahan, Z.H., Dupont, H.L. The history of acute infectious diarrhoea management-from poorly focused empiricism to fluid therapy and modern pharmacotherapy. Alimentary Pharmacol. Therapeutics., 2007; 25(7):759-769.

[6] Hankin, E.H. L'action bactéricide des eaux de la Jumna et du Gange sur le vibrion du choléra. Ann. Inst. Pasteur, 1896; 10:511-523.

[7] Arora, N.K., Tewari, S., Singh, S. Analysis of water quality parameters of River Ganga during Maha Kumbh, Haridwar, India. J. Environ. Biol., 2013; 34:799-803.

[8] Aitken, M.D. et al. Inactivation of Escherichia coli O157: H7 during thermophilic anaerobic digestion of manure from dairy cattle. Water Res., 2007; 41(8):1659-1666.

[9] Chart, H. VTEC enteropathogeicity. J. Appl . Microbiol., 2000; 88:12S-23S (Symposium Supplement).

[10] Lock, R.L., Harry, E.J. Cell-division inhibitors: new insights for future antibiotics. Nature Rev. Drug. Dis., 1994; 7:324-338.

[11] Rossi, L. M., Rangaswamy, P., Zhang, J. et al. Research advances in the development of peptide antibiotics. J. Pharm. Sci., 2008; 97:1060-1070.

[12] Walsh, C. Where will new antibiotics come from? Nature Rev. Microbiol., 2003; 1(1):65-70.

[13] Anonymous. Study to look into medicinal value of river Ganga water. The Pioneer, 17 November, 2015, New Delhi.

[14] Sutton, S. Measurement of cell concentration in suspension by optical density. Pharm. Microbiol., 2006; 12(8):3-13.

[15] ISI-1055. Indian Standard: Tolerance limits for inland surface waters subject to pollution. BIS, New Delhi, India, 1991.

[16] Kumarswami, P., Vignesh, S. Estimation and identification of pathogenic pollution indicator in Cauveri river, South India. Res. J. Microbiol., 2009; 4:540-549.

[17] Nautiyal, C.S. Self-purificatory Ganga water facilitates death of pathogenic Escherichia coli O157:H7. Curr. Microbiol., 2009; 58(1):25-29.

[18] Flint, K.P. The long-term survival of Escherichia coli in river water. J. Appl. Bacteriol., 1987; 63:261-270.

[19] Cursino, L., Smajs, D., Smarda, J., Nardi, R.M.D. et al. Exoproducts of the Escherichia coli strain H22 inhibiting some enteric pathogens both in vitro and in vivo. J. Appl. Microbiol., 2006; 100(4):821-829.

[20] Tyagi, S., Dubey, R.C. Isolation of host specific bacteriophages from Ganga water against some enteric bacterial pathogens of human. J. Sci. Trans. Environ. Technov., 2018; 12(1):1-5

Indo Global Journal of Pharmaceutical Sciences( ISSN 2249 1023; CODEN- IGJPAI; NLM ID: 101610675) indexed and abstracted in CrossRef (DOI Enabling), CNKI, UGC CARE Journal List, EMBASE (Elsevier), National Library of Medicine (NLM) Catalog (NCBI), ResearchGate, Publons (Clarivate Analytics), CAS (ACS), Index Copernicus, Google Scholar and many more. For further details, visit http://iglobaljournal.com 